\title{
Efficacy of bacteriophage treatment against carbapenem-resistant Acinetobacter baumannii in Galleria mellonella larvae and a mouse model of acute pneumonia
}

\author{
Jongsoo Jeon ${ }^{1 *}$, Jong-Hwan Park ${ }^{2}$ and Dongeun Yong ${ }^{1,3^{*}}$ (i)
}

\begin{abstract}
Background: Acinetobacter baumannii is an opportunistic pathogen that causes serious nosocomial infection in intensive care units. In particular, carbapenem-resistant A. baumannii (CRAB) strains have been increasing in the past decade, and they have caused major medical problems worldwide. In this study, a novel A. baumannii lytic phage, the YMC 13/03/R2096 ABA BP (phage B $\phi$-R2096), which specifically causes the lysis of CRAB strains, was characterized in detail in vitro and in silico, and the in vivo effectiveness of phage therapy was evaluated using Galleria mellonella and a mouse model of acute pneumonia.

Results: The A. baumannii phage B $\phi-R 2096$ was isolated from sewage water using CRAB clinical strains selected from patients at a university hospital in South Korea. The complete genome of the phage $B \phi-R 2096$, which belongs to the Myoviridae family, was analyzed. Phage B $\phi$-R2096 inhibited bacterial growth in a dose-dependent manner and exhibited high bacteriolytic activity at $\mathrm{MOI}=10$. In the evaluation of its therapeutic potential against CRAB clinical isolates using two in vivo models, phage B $\phi$-R2096 increased the survival rates of both G. mellonella larvae (from 0 to $50 \%$ at $24 \mathrm{~h}$ ) and mice (from $30 \%$ with $\mathrm{MOI}=0.1$ to $100 \%$ with $\mathrm{MOI}=10$ for 12 days) in post-infection of CRAB. In particular, phage B $\phi$-R2096 strongly ameliorated histologic damage to infected lungs, with bacterial clearance in the lungs observed on day 3 postinfection in the mouse acute pneumonia model. Moreover, in vivo studies revealed no mortality or serious side effects in phage-treated groups.

Conclusion: The results of this study strongly suggest that phage B $\phi-R 2096$, a novel A. baumannii lytic phage, could be an alternative antibacterial agent to control CRAB infections. This study is the first report to compare in vivo evaluations ( $G$. mellonella larvae and a mouse acute pneumonia model) of the therapeutic efficacy of a phage against CRAB infections.
\end{abstract}

Keywords: Bacteriophage, Carbapenem, Acinetobacter baumannii, Myoviridae, Phage therapy, Galleria mellonella, Mouse acute pneumonia

\section{Background}

The emergence and rise of antibiotic-resistant bacteria related to the use of broad-spectrum antibiotics has been reported [1-3]. Recently, pandrug-resistant pathogens, which are resistant to all commercially available

\footnotetext{
* Correspondence: pulipisle05@hanmail.net; deyong@yuhs.ac ${ }^{1}$ Department of Laboratory Medicine and Research Institute of Bacterial Resistance, Y, Seoul, Republic of Korea

Full list of author information is available at the end of the article
}

antibiotics, have become significant therapeutic challenges worldwide [4].

Acinetobacter baumannii, a Gram-negative coccobacillus, is an important global nosocomial pathogen species that causes infections such as bacteremia, pneumonia, urinary tract infections, wound infections, and meningitis in critically immunocompromised patients in intensive care units (ICUs) [5]. The rapid spread of multidrug-resistant (MDR) A. baumannii, one of the ESKAPE (Enterococcus faecium, Staphylococcus aureus,

(c) The Author(s). 2019 Open Access This article is distributed under the terms of the Creative Commons Attribution 4.0 International License (http://creativecommons.org/licenses/by/4.0/), which permits unrestricted use, distribution, and reproduction in any medium, provided you give appropriate credit to the original author(s) and the source, provide a link to the Creative Commons license, and indicate if changes were made. The Creative Commons Public Domain Dedication waiver (http://creativecommons.org/publicdomain/zero/1.0/) applies to the data made available in this article, unless otherwise stated. 
Klebsiella pneumoniae, Acinetobacter baumannii, Pseudomonas aeruginosa, and Enterobacter species) pathogens, is of great concern in hospitals around the globe $[6,7]$.

Carbapenems have been the most effective antibiotics against the serious infections caused by Acinetobacter spp.; however, carbapenem resistance rates among $A$. baumannii isolates have increased significantly in many countries, including the USA [8], China [9], and South Korea $[10,11]$, since the first reported emergence in New York, USA, in 1991 [12]. Infections caused by carbapenem-resistant $A$. baumannii (CRAB) are difficult to treat due to limited of therapeutic options, and they are associated with high mortality and economic costs driven by long hospital stays [13-16].

Acinetobacter baumannii's ability to acquire resistance has increased rapidly. Carbapenem resistance is caused by several mechanisms, including the loss of outer membrane proteins, overexpression of efflux pumps and metallo-beta-lactamase [17, 18]. The carbapenem resistance of $A$. baumannii isolates is mostly due to the production of OXA-type carbapenemases (class D carbapenemase-hydrolyzing oxacillinases) [19-21].

Colistin is an alternative agent that retains high activity against all Gram-negative bacilli, including MDR $A$. baumannii [22]. However, it is limited by dose-limiting toxicity and efficacy. Moreover, since the first report in the Czech Republic in 1999, increasing incidents of $A$. baumannii resistance to colistin have been reported in many countries [23-26]. Therefore, the need to develop novel antibacterial agents and strategies to control hospital infections caused by MDR A. baumannii is urgent [27-31].

Bacteriophages (phages) are natural viruses that infect bacteria and exist as one of the most abundant biological entities in the biosphere [32]. Since their discovery by Frederick Twort in 1915 and Felix d'Herelle in 1917, clinical approaches for phage therapy have been reported in the USA, Georgia, Poland and Russia; however, phage therapy declined sharply with the introduction of antibiotics in the 1940s [31, 33]. Currently, phages have been reviewed for application as novel alternative agents to combat antimicrobial pathogen challenges caused by the emergence and increase of antibiotic resistance worldwide [34-36].

Since Soothill et al. [37] first reported that phage BS46 had therapeutic potential in vivo to treat systemic infections caused by $A$. baumannii, researchers have studied lytic phages for MDR Acinetobacter spp. and suggested them as alternative therapeutics and environmental disinfectants for hospital ICUs [38-44].

Recently, the emergence of phage-resistant mutants to single phages through the mechanisms of phage-resistance has been one of the major concerns in the phage therapy
[45]. For this reason, the application of phage cocktails has been used to significantly reduce the evolution of resistant bacteria, and to maintain higher lytic efficacy [46]. Nevertheless, for the fundamental data to formulate a safe and effective phage cocktail, it is important to isolate new bacteriophages and to accumulate information on the characterization of individual phages from experiments in vitro and in vivo [47].

In the present study, we isolated and characterized a novel A. baumannii phage, $\mathrm{B} \phi-\mathrm{R} 2096$, in vitro and in silico, including its bacteriolytic activity and a whole genome sequence analysis. We also evaluated the in vivo therapeutic potential of phage B $\phi-R 2096$ against CRAB infection. A Galleria mellonella model has been used for several years as a tool to assess the virulence of bacterial pathogens and evaluate the therapeutic efficacy of phages against bacterial infections [48-51]. Therefore, we performed in vivo evaluations of the phage therapy using both the Galleria mellonella model and a mouse model of acute pneumonia. To the best of our knowledge, this study is the first to confirm experimental details comparing the therapeutic effects of an A. baumannii phage against $\mathrm{CRAB}$ clinical strains using G. mellonella (wax worms) and a mouse model of acute pneumonia.

\section{Results}

Characterization of carbapenem-resistant Acinetobacter baumannii clinical isolates

The 20 CRAB clinical isolates were resistant to ceftazidime, cefepime, cefotaxime, imipenem, meropenem, piperacillin-tazobactam, and cotrimoxazole, but not colistin and tigecycline. Specifically, the host bacterium of phage B $\phi-\mathrm{R} 2096$, A. baumannii YMC13/03/R2096, was resistant to piperacillin-tazobactam, ceftazidime, cefotaxime, cefepime, imipenem, meropenem, gentamicin, amikacin, levofloxacin, and cotrimoxazole, but not ampicillin-sulbactam, colistin, minocycline, or tigecycline (Additional file 1: Table S1). PFGE of 31 carbapenem-resistant and -susceptible A. baumannii strains showed different clonality with distinguishable restriction patterns (Additional file 1: Figure S1), and MLST analysis of the $20 \mathrm{CRAB}$ strains, including A. baumannii YMC13/03/R2096, indicated that they were sequence type (ST) 357 (allelic profile 1-12-3-2-2-145-3), which belongs to European clone II. All strains had a $b l a_{\text {OXA-66-like gene, which confers carbapenem resistance }}$ (Additional file 1: Table S1). We used A. baumannii YMC13/03/R2096 for the in vitro characterization and in vivo study of phageB $\phi-R 2096$.

\section{Characterization of phage $\mathrm{B} \varphi-\mathrm{R} 2096$ infecting carbapenem-resistant $A$. baumannii strains}

As shown Fig. 1a, electron microscopy indicated that phage $\mathrm{B} \phi-\mathrm{R} 2096$ belongs to the Myoviridae family, with 


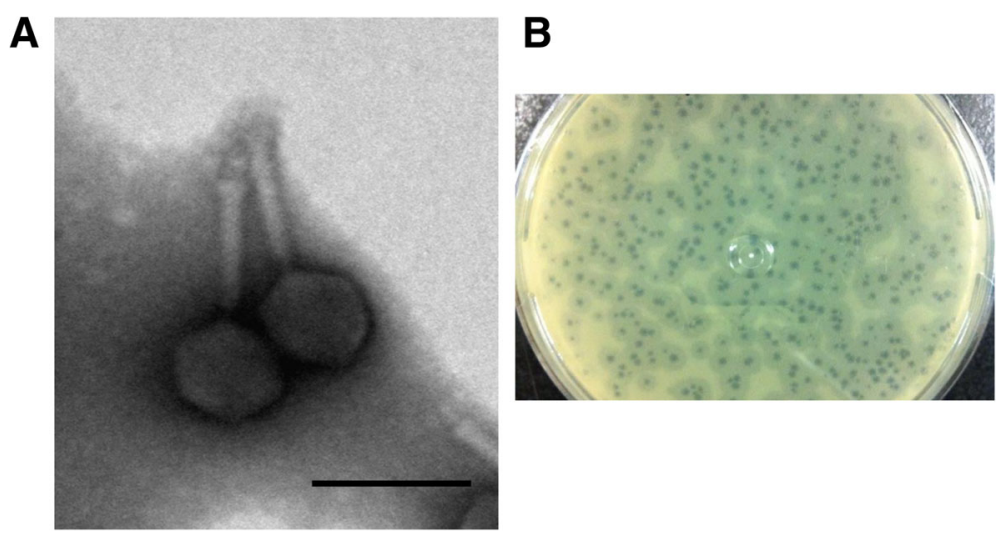

Fig. 1 The morphology (a) of $A$. baumannii phage $B \varphi-R 2096$ as shown by transmission electron microscopy and plaque formation (b) of $A$. baumannii phage $B \varphi$-R2096. The phage was placed onto a carbon-coated copper grid and negatively stained with $2 \%$ uranyl acetate for $15 \mathrm{~s}$. The scale bar $=100 \mathrm{~nm}$

an isometric head approximately $60 \mathrm{~nm}$ in diameter and a contractile tail approximately $89 \mathrm{~nm}$ in length $(n=15)$. The phage $\mathrm{B} \phi-\mathrm{R} 2096$ formed clear plaques of $2-3 \mathrm{~mm}$, and observed plaque-surrounding halos on agar plates. In the adsorption rate and one step growth curve analysis, phage $\mathrm{B} \phi-\mathrm{R} 2096$ exhibited an adsorption rate of $83 \%$ within $2 \mathrm{~min}$ and $95 \%$ within $5 \mathrm{~min}$ (Additional file 1: Figure S2 A), a latent period of $50 \mathrm{~min}$, and a burst size of $142 \mathrm{PFU}$ per infected cell (Additional file 1: Figure S2 B). Its temperature and $\mathrm{pH}$ stability were evaluated in the $25-70{ }^{\circ} \mathrm{C}$ and $\mathrm{pH} 4-10$ ranges (Additional file 1: Figure S3). Phage B $\phi-R 2096$ showed high stability at $25^{\circ} \mathrm{C}(>99 \%)$ for up to $9 \mathrm{~h}$ and maintained activities of 58,47 , and $24 \%$ at $40^{\circ} \mathrm{C}, 50^{\circ} \mathrm{C}$, and $60^{\circ} \mathrm{C}$, respectively, for up to $9 \mathrm{~h}$, but it showed no activity at $70^{\circ} \mathrm{C}$ at any time point (Additional file 1: Figure S3 A). In the $\mathrm{pH}$ stability test, $>60 \%$ of phage $\mathrm{B} \phi-\mathrm{R} 2096$ was retained at $\mathrm{pH} 7, \mathrm{pH} 7.5$, and $\mathrm{pH} 8$, and it also showed significant stability (>40\%) at $\mathrm{pH} 10$ during the 10 month study (Additional file 1: Figure S3 B).

\section{Host spectrum test of $A$. baumannii phage $B \varphi-R 2096$}

In the host spectrum assay of phage $\mathrm{B} \phi-\mathrm{R} 2096$ against 40 clinical strains (20 carbapenem-resistant $A$. baumannii, 11 carbapenem-susceptible $A$. baumannii, 3 carbapenem- and colistin-resistant $A$. baumannii, 3 carbapenem-resistant $P$. aeruginosa, and 3 carbapenem-resistant $E$. coli), phage $\mathrm{B} \phi-$ R2096 formed a clear zone on 16 of the 20 carbapenem-resistant $A$. baumannii strains and 1 of the 3 carbaepenemand colistin-resistant $A$. baumannii strains with EOP of $\geq 0.5$ (Table 1). However, we could not measure the EOP in the other 23 isolates. Thus, phage B $\phi-\mathrm{R} 2096$ has strong species and strain specificity and is a relatively broad host-spectrum phage for carbapenem-resistant $A$. baumannii isolates.

\section{Host cell lytic activity test of phage $B \varphi-R 2096$}

The bacteriolytic effect of phage $\mathrm{B} \phi-\mathrm{R} 2096$ on the $A$. baumannii YMC13/03/R2096 isolate in vitro is shown in Fig. 2. The absorbance $\left(\mathrm{OD}_{600}\right)$ of the uninfected control culture increased rapidly $\left(\mathrm{OD}_{600}=1.49,6 \mathrm{~h}\right)$, whereas all phage-B $\phi-\mathrm{R} 2096$-infected cultures showed significantly inhibited bacterial growth after $3 \mathrm{~h}(\mathrm{MOI}=10$, $\mathrm{OD}_{600}=0.37,6 \mathrm{~h}$ ), although the bactericidal effect exhibited slight differences with changes in the MOI (Fig. 2).

\section{Genome sequencing and bioinformatics analysis}

The genome of phage $\mathrm{B} \phi-\mathrm{R} 2096$ was sequenced with 58,755 read lengths and 285-fold coverage. The linear dsDNA of phage B $\phi-R 2096$ was illustrated in Fig. 3a as a circular form using DNAPlotter. The phage B $\phi-R 2096$ genome was annotated 32 of the 162 ORFs in the phage $\mathrm{B} \phi-\mathrm{R} 2096$ genome, and among them, 12 predicted proteins for phage structures (orf 41, orf 43, orf 44, orf 46, orf 51, orf 55, orf 56, orf 62). The DNA metabolism modules (orf 81, orf 87, orf 88, orf 89) exhibited 24-51\% protein sequence similarity with $A$. baumannii phage vB_AbaM_Acibel004 (GenBank accession no. NC_025462) in the BlastP database (Additional file 1: Table S2). Also, the putative tail fiber (orf 34) and putative endolysin (orf 68) revealed 71 and $56 \%$ of sequence similarity with $A$. baumannii phage AM24 and A. baumannii phage AP22, respectively (Additional file 1: Table S2). However, the whole genome of the novel phage $\mathrm{B} \phi-\mathrm{R} 2096$ has no BlastN matches with any other Acinetobacter phage genomes, except for Acinetobacter phage AM24 (GenBank accession number KY000079). As shown in Fig. 3b, the genomic structure of phage B $\phi-\mathrm{R} 2096$ was compared with that of phage AM24. This alignment indicates that the gene organization of phage B $\phi-\mathrm{R} 2096$ and phage AM24 are similar, and share an overall high DNA sequence similarity (the 
Table 1 Clinical strains used in this study and their sensitivity to A. baumannii phage B $\phi$-R2096

\begin{tabular}{|c|c|c|c|c|c|c|c|}
\hline Species and strains & & $\begin{array}{l}\text { Sensitivity }{ }^{a} \text { to } \\
\text { phage } B \phi-R 2096\end{array}$ & $\mathrm{EOP}^{\mathrm{b}}$ & Species and strains & & $\begin{array}{l}\text { Sensitivity to } \\
\text { phage } B \phi-R 2096\end{array}$ & EOP \\
\hline \multirow{20}{*}{$\begin{array}{l}\text { Carbapenem-resistant } \\
\text { A. baumannii }\end{array}$} & YMC13/03/R2096 & ++ & 1.0 & \multirow{11}{*}{$\begin{array}{l}\text { Carbapenem-susceptible } \\
\text { A. baumannii }\end{array}$} & YMC13/05/R728 & - & \\
\hline & YMC13/01/R1400 & ++ & 0.9 & & YMC13/05/R550 & - & \\
\hline & YMC13/01/R1224 & + & 0.6 & & YMC13/01/R588 & - & \\
\hline & YMC13/01/R1919 & + & 0.6 & & YMC13/06/R2026 & - & \\
\hline & YMC13/01/R187 & + & 0.5 & & YMC13/01/R722 & - & \\
\hline & YMC13/01/R2058 & + & 0.6 & & YMC13/06/R1660 & - & \\
\hline & YMC13/01/R1238 & + & 0.7 & & YMC13/04/R3097 & - & \\
\hline & YMC13/01/R249 & ++ & 0.9 & & YMC13/01/R3428 & - & \\
\hline & YMC13/01/R280 & ++ & 0.9 & & YMC13/05/R407 & - & \\
\hline & YMC13/01/R224 & ++ & 0.8 & & YMC13/04/R3148 & - & \\
\hline & YMC13/01/R656 & + & 0.6 & & YMC13/01/R3291 & - & \\
\hline & YMC13/03/R12096 & + & 0.7 & \multirow{3}{*}{$\begin{array}{l}\text { Colistin-resistant } \\
\text { A. baumannii }\end{array}$} & YMC13/07/ R3044 & + & 0.5 \\
\hline & YMC13/01/R317 & + & 0.5 & & YMC13/08/R2633 & - & \\
\hline & YMC13/01/R129 & + & 0.5 & & YMC13/09/R888 & - & \\
\hline & YMC13/01/R3197 & + & 0.6 & \multirow{3}{*}{$\begin{array}{l}\text { Carbapenem-resistant } \\
\text { Pseudomonas aeruginosa }\end{array}$} & YMC13/01/B10214 & - & \\
\hline & YMC13/04/B720 & + & 0.6 & & YMC13/01/ B11605 & - & \\
\hline & YMC13/02/R291 & - & & & YMC13/03/ B9708 & - & \\
\hline & YMC13/02/R319 & - & & \multirow{3}{*}{$\begin{array}{l}\text { Carbapenem-resistant } \\
\text { Escherichia coli }\end{array}$} & YMC13/01/ B9566 & - & \\
\hline & YMC13/02/R401 & - & & & YMC13/01/ B10710 & - & \\
\hline & YMC13/02/R427 & - & & & YMC13/01/ B11097 & - & \\
\hline
\end{tabular}

aphage activity against collected bacteria: ++ , clear plaque; + , turbid plaque; - , no plaque

${ }^{\mathrm{b}}$ The efficiency of plating (EOP) was calculated as the titer (PFU/ml) on the test bacteria strain divided by titer (PFU/ml) on host bacteria strain

query coverage of $81 \%$, the max identity of $98 \%$ ). The virulence and lysogeny-related genes (encoding protein such as integrase) were not detected in the phage B $\phi-\mathrm{R} 2096$ genome. In phage $\mathrm{B} \phi-\mathrm{R} 2096$ genome, 239 promoters and 45 rho-independent transcription terminators were predicted by using BPROM and ARNold software, respectively.

\section{Therapeutic effect of phage $B \varphi-R 2096$ against CRAB in Galleria mellonella infection model}

We used Galleria mellonella larvae as an animal model to evaluate the effectiveness of $A$. baumannii phage $\mathrm{B} \phi-\mathrm{R} 2096$ as a therapy against the YMC13/03/R2096 strain of CRAB. G. mellonella larvae were treated with concentrated phage $\mathrm{B} \phi-\mathrm{R} 2096\left(1 \times 10^{10} \mathrm{PFU}\right)$ at two MOIs (MOI 100 and 10) $30 \mathrm{~min}$ after infection with CRAB $\left(1 \times 10^{8} \mathrm{CFU}\right)$. The results in Fig. 4a show that the bacteria-only-infection group died rapidly: 90 and $100 \%$ of larvae were dead at $16 \mathrm{~h}$ and $24 \mathrm{~h}$, respectively. However, the postinfection phage-treatment larval group at an MOI of 100 had a survival rate of 80 and $50 \%$ at $16 \mathrm{~h}$ and $48 \mathrm{~h}$, respectively. There was a statistically significant improvement in survival rates of larvae treated with phage at MOI of 100 and untreated control larvae $(p<0.0001)$ at $48 \mathrm{~h}$. The phage-treated larval group at an MOI of 10 exhibited $45 \%$ survival at $16 \mathrm{~h}$, but this group showed only $10 \%$ survival at $48 \mathrm{~h}$. The two groups injected with buffer $(\mathrm{PBS}+\mathrm{SM})$ and concentrated phage solution $\left(1 \times 10^{10} \mathrm{PFU}\right)$ showed no mortality or signs of melanization after $48 \mathrm{~h}$; thus, the phage caused no virulence, and the injection caused no trauma.

To observe the effects of phage therapy in the larval tissue, we examined the histology of larvae from each experimental group. As shown in Fig. 4b, many melanized nodules were detected in various areas of larval tissue from the bacteria-only-treatment group $\left(1 \times 10^{8}\right.$ $\mathrm{CFU})$; however, the larval group that received postinfection phage treatment (MOI 100) had significantly less tissue damage and melanization in the fat body well and the muscle layer than the group that received only bacteria. Furthermore, the phage-only-treatment $\left(1 \times 10^{10}\right.$ $\mathrm{PFU})$ groups did not exhibit any tissue damage not also seen in the buffer-only-treatment (PBS + SM) group.

\section{Therapeutic effect of phage against CRAB in a mouse model of acute pneumonia}

We investigated the survival rate in a mouse model of acute pneumonia to assess the therapeutic effect and safety of $A$. baumannii phage $\mathrm{B} \phi-\mathrm{R} 2096$ as an antibacterial agent. As shown in Fig. 5, A. baumannii phage B $\phi-R 2096$ exhibited excellent elimination of the target 


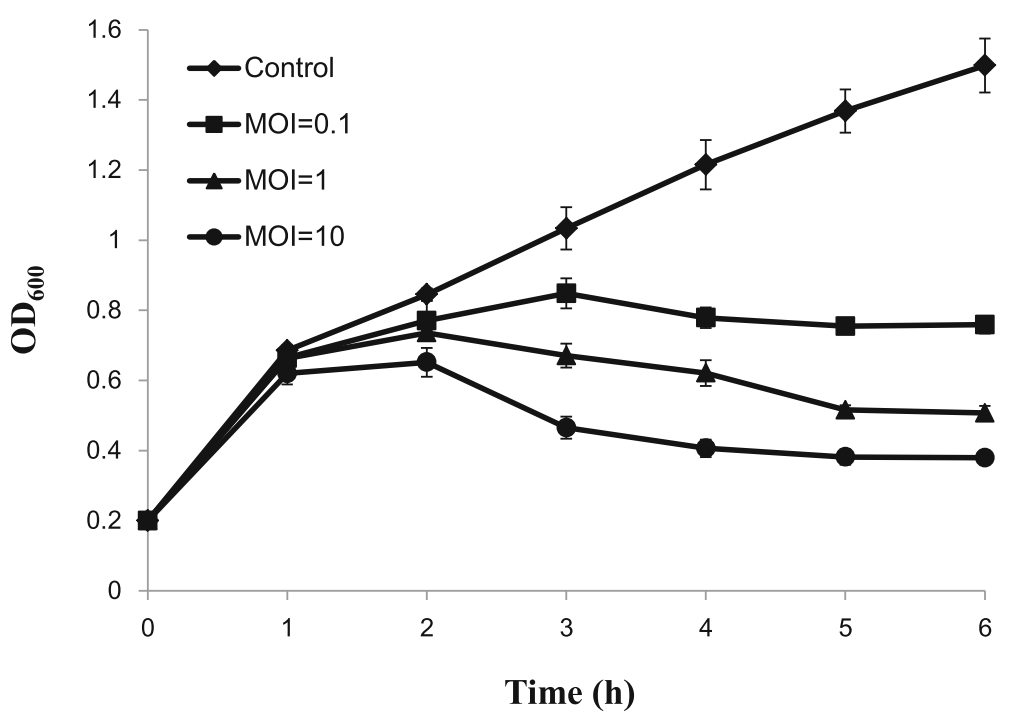

Fig. 2 Time course of cell lysis by A. baumannii phage B $\varphi-R 2096$ on carbapenem-resistant A. baumannii YMC13/03/R2096 strain. The host bacterium, A. baumannii YMC13/03/R2096, was infected with phage B $\varphi-R 2096$ at MOls of 0.1, 1, and 10. The turbidity of the bacterial cultures was measured by spectrophotometer at $\mathrm{OD}_{600}$. Data are presented as the mean \pm standard deviation

bacteria. The bacteria-only-treatment mouse group all died by day 5 postinfection; however, the mouse groups who received phage treatment at 30 min postinfection showed high survival rates on day 12 at $\mathrm{MOI}=10$ $(100 \%), \mathrm{MOI}=1(60 \%)$, and $\mathrm{MOI}=0.1(30 \%)$. Moreover, no mice in the phage-only group or the control group (buffer-treated) died and lost weight (Additional file 1: Figure S4).

\section{Histological changes and cytokines}

We used a histological analysis and the immunogenicity of lung samples to evaluate the efficacy of the phage therapy in the mouse acute pneumonia model. We compared the histological changes in the lung tissues from each group using H\&E staining (Fig. 6a). The bacteria-only-treatment group sustained significant damage, such as severe thickening of the alveolar walls and hemorrhaging in the alveolar space, on days 1 and 3, but the group that received phage treatment postinfection showed only a slight region of mild or moderate alveolar wall thickening. Moreover, the group that received only phages showed no histological changes compared with the control (buffer-treated) group on days 1

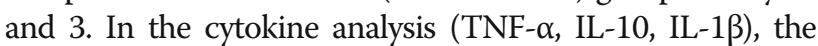
levels of TNF- $\left.\alpha{ }^{(* * * * *} p<0.0001\right)$, IL-6 ( $\left.{ }^{* * * * *} \mathrm{p}<0.0001\right)$, except IL-1 $\beta$ (no significant difference), in the lungs of the postinfection phage-treatment group were significantly reduced compared with the bacteria-only-treatment group on day 1 . The phage-only-treated group and control (buffer-treated) group exhibited no appreciable levels of TNF- $\alpha$, IL-6 or IL-1 $\beta$ (Additional file 1: Figure S5).

\section{Bacterial clearance and phage count}

We measured the number of bacteria and phages in mouse lungs from each group on days 1 and 3. Each point of Fig. 6 (b) and (c) indicates the bacterial or phage counts of a single mouse. The bacterial load in the lungs of the postinfection phage-treatment group declined $>2 \log _{10} \mathrm{CFU}$ $(* * * * 0<0.001)$ compared with the bacteria-only-treatment group on day 1 , and in the postinfection phage-treatment group, bacteria were cleared completely from most of the mouse lungs on day 3 (Fig. 6b). Viable bacteria were not detected in the buffer only and phage-only-treatment groups (data not shown) at the same time points. In phage counts in the mouse lungs, the PFU value in the postinfection phage-treatment group was significantly higher $(>6$ $\log _{10}$ PFU, $\left.{ }^{* * * * *} p<0.0001\right)$ than in the phage-only-treatment group on day 1 . By day 3 , the number of phages in the postinfection phage-treatment group had decreased significantly (12.2 to $7.7 \log _{10}$ PFU), and the PFU value of the phage-only-treatment group had declined from 6.2 to 2.3 $\log _{10}$ PFU (Fig. 6c). In this test, the control (buffer-treated) group and the bacteria-only-treatment group (data not shown) had no detectable phage plaques at any time point.

\section{Discussion}

The development of new antibiotics and their dramatic effect on bacterial diseases have improved human life since the middle of the twentieth century, but unfortunately the emergence and worldwide spread of MDR bacteria has become a major global challenge [52].

MDR bacteria are resistant to at least three different classes of antibiotics, such as carbapenems, aminoglycosides, 


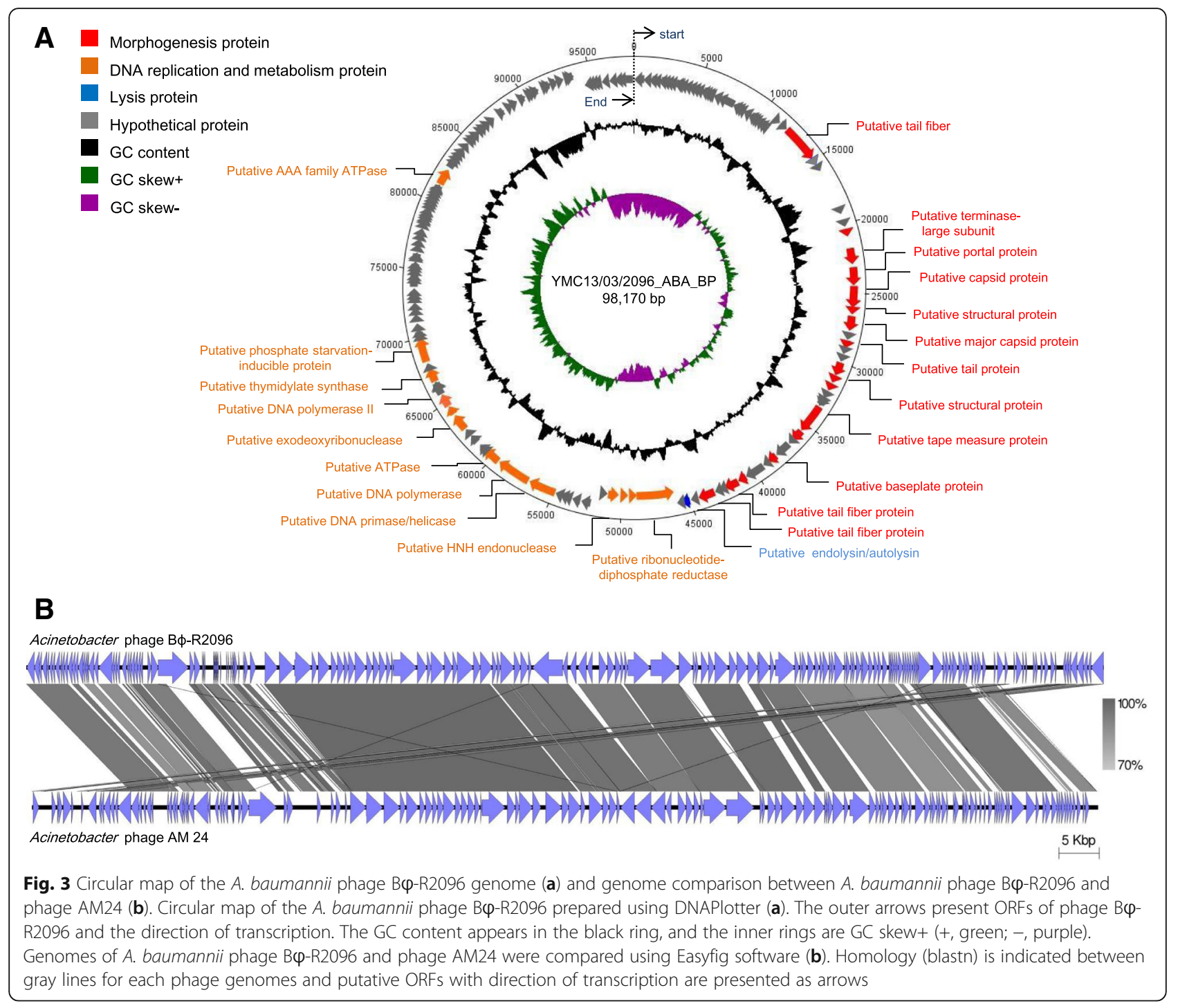

and quinolones [53]. MDR Acinetobacter spp., including $\mathrm{CRAB}$, have been increasing during the past decade and are of great medical concern worldwide [22]. Because the need to control MDR infections is urgent, phages are being newly studied as potential antibiotic alternatives. Phage-related therapy has unique advantages, including high specificity to target pathogens, self-replication, and low toxicity, compared with commercial antibiotics [30, 35], which explains why the therapeutic effects of various phages against many MDR bacterial infections, such as Staphylococcus aureus, P. aeruginosa, and E. coli, have been widely studied in animals [54-57].

In 2006, the US FDA approved food applications of phages to eliminate food-borne pathogens such as Listeria monocytogenes, Salmonella spp., and Shigella spp. $[35,58]$. Thus, bacteriophages are safe in humans and stable in the environment, so they can be applied as alternative therapeutic agents.
The purpose of this study was to characterize novel Acinetobacter phage B $\phi-\mathrm{R} 2096$, which lyses MDR Acinetobacter spp. including CRAB clinical isolates, in detail and to provide in vivo data on the therapeutic effects of phage B $\phi-R 2096$ against CRAB clinical isolates in G. mellonella infection and mouse acute pneumonia models.

In this study, the host bacterium, CRAB YMC13/03/ R2096 strain, isolated from a patient is an ST 357 strain belonging to EU clone II [59]. Especially, 16S rRNA methylase ArmA gene which has high level of resistance to various aminoglycosides also was identified in this organism (data not shown) [60].

The morphological features of phage $\mathrm{B} \phi-\mathrm{R} 2096$ indicate that it is part of the family Myoviridae; it is similar to other Myoviral Acinetobacter phage AP22 [61] and vB_AbaM-IME-AB2 [40] (Fig. 1). The phage B $\phi-R 2096$ formed clear round plaques, and showed plaque-surrounding 


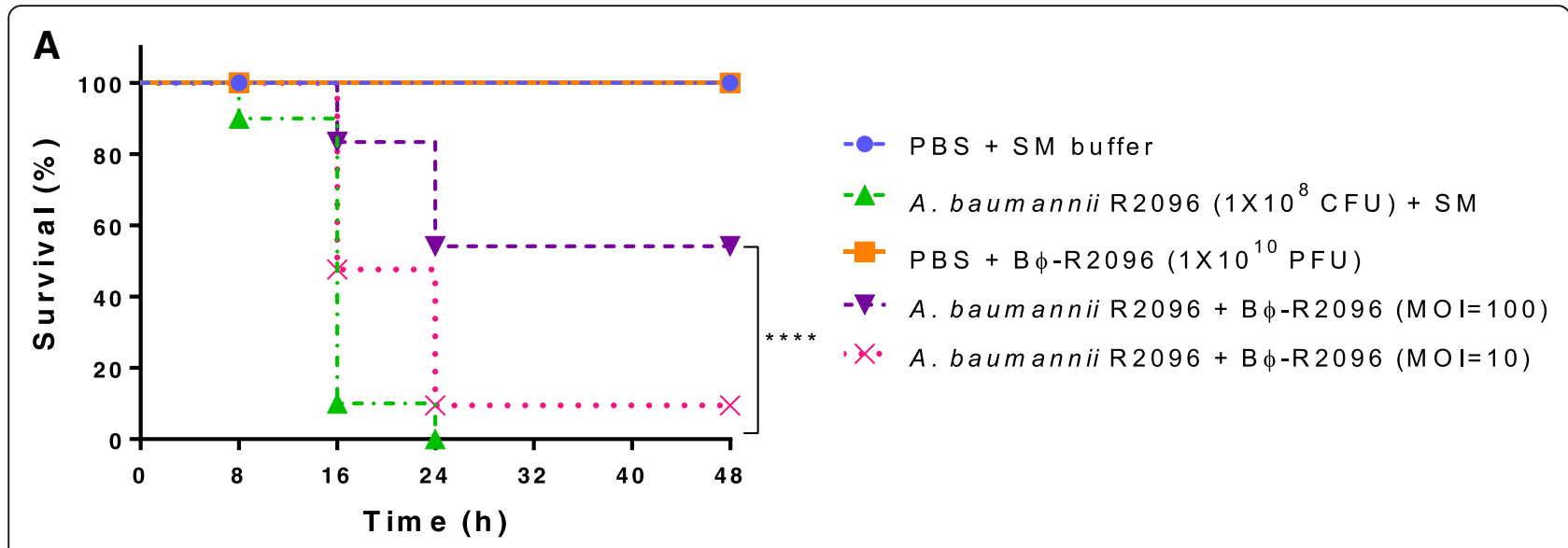

B $\mathrm{B} \phi-\mathrm{R} 2096$ A. baumannii A. baumannii + $\mathrm{B} \phi-\mathrm{R} 2096$
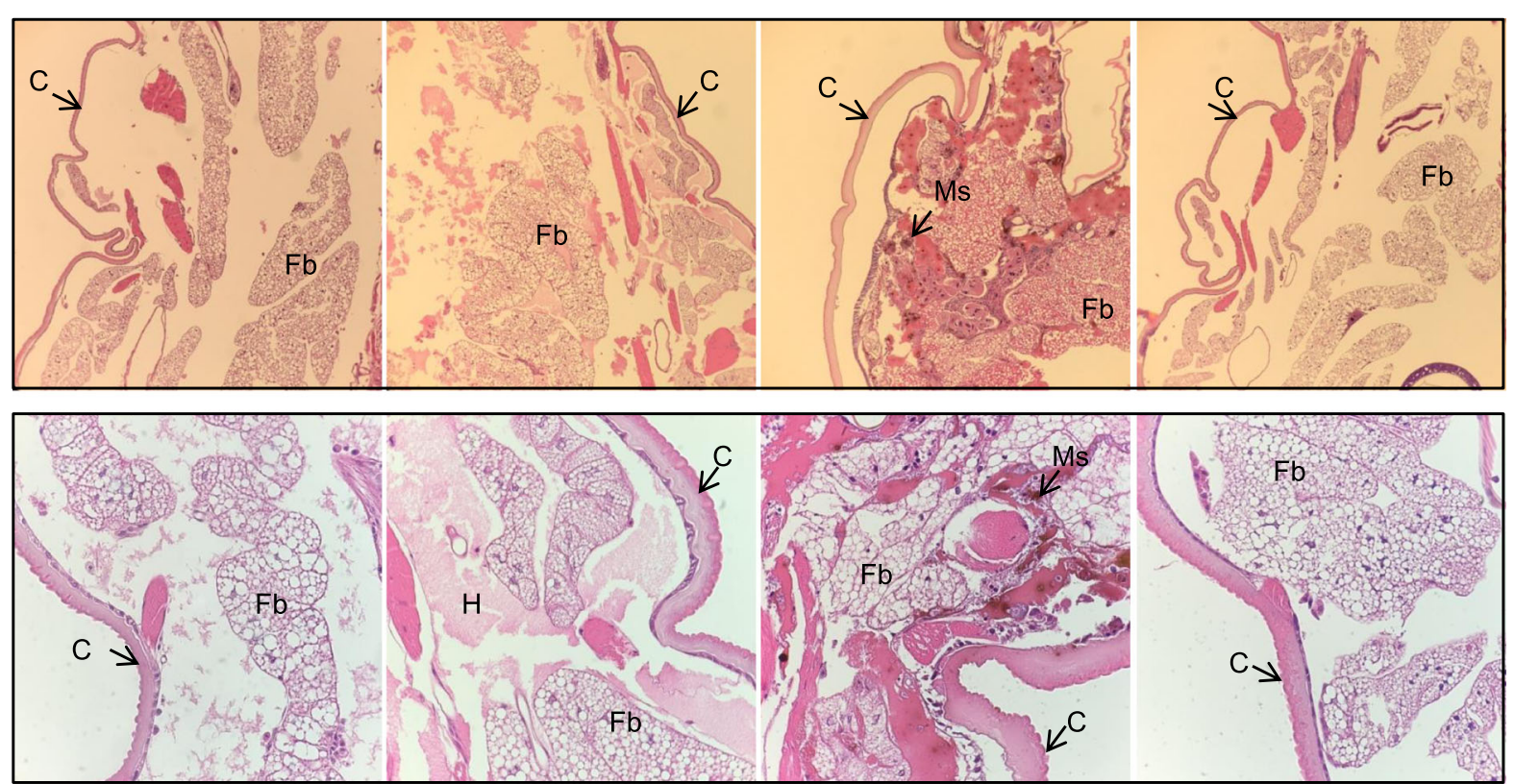

Fig. 4 Survival of G. mellonella larvae treated with A. baumannii phage B $\varphi$-R2096 against carbapenem-resistant A. baumannii YMC13/03/R2096 (a) and histological features of the G. mellonella larvae (b). G. mellonella larvae treated with A. baumannii phage B $\varphi$-R2096 (MOI 100 and 10) after infection with CRAB YMC13/03/R2096, including the survival of each larval group, were monitored at 8-h intervals for $48 \mathrm{~h}$. Tissue sections of larvae from each group were stained at $24 \mathrm{~h}$ with hematoxylin and eosin and observed at a magnification of $\times 10$ (upper column) and $\times 40$ (down column). C: cuticle; Fb: fat body; H: hemolymph; Ms.: melanized structures. The percentage of G. mellonella survival at each time point is presented using the log-rank (Mantel-Cox) test (GraphPad Prism v 5.03). The results show the average of three independent trials $(n=20$ larvae per group). Log-rank (Mantel-Cox) test, ${ }^{* * * *} p<0.0001$

halos which are associated with phage-derived depolymerases on agar plates. This phenomenon indicates the presence of depolymerase activity which degrades capsular exopolysaccharides producing bacteria [62].

In vitro characterization of phage $\mathrm{B} \phi-\mathrm{R} 2096$ showed that it has a high adsorption rate and burst size (Additional file 1: Figure S2). In particular, this phage was relatively stable at high temperatures and more stable at an alkaline $\mathrm{pH}$ than an acidic $\mathrm{pH}$ for up to 10 months (Additional file 1: Figure S3). These results suggest that phage $\mathrm{B} \phi-\mathrm{R} 2096$ is more stable for long periods in storage and various physiological conditions than that of previous reports $[39,63,64]$. In the host spectrum using spot test, phage B $\phi-\mathrm{R} 2096$ exhibited a specific and broad host range on the ST357 CRAB strains. Especially; efficiency of plating (EOP) assay was performed to assess a quantitative measure and possible "lysis from without" phenomenon of lytic activities of phage B $\phi-R 2096$ against CRAB strains (Table 1) [65]. In the host cell lysis test, phage B $\phi-R 2096$ strongly prevented bacterial growth dose dependently in vitro (Fig. 2). This result indicates that phage 


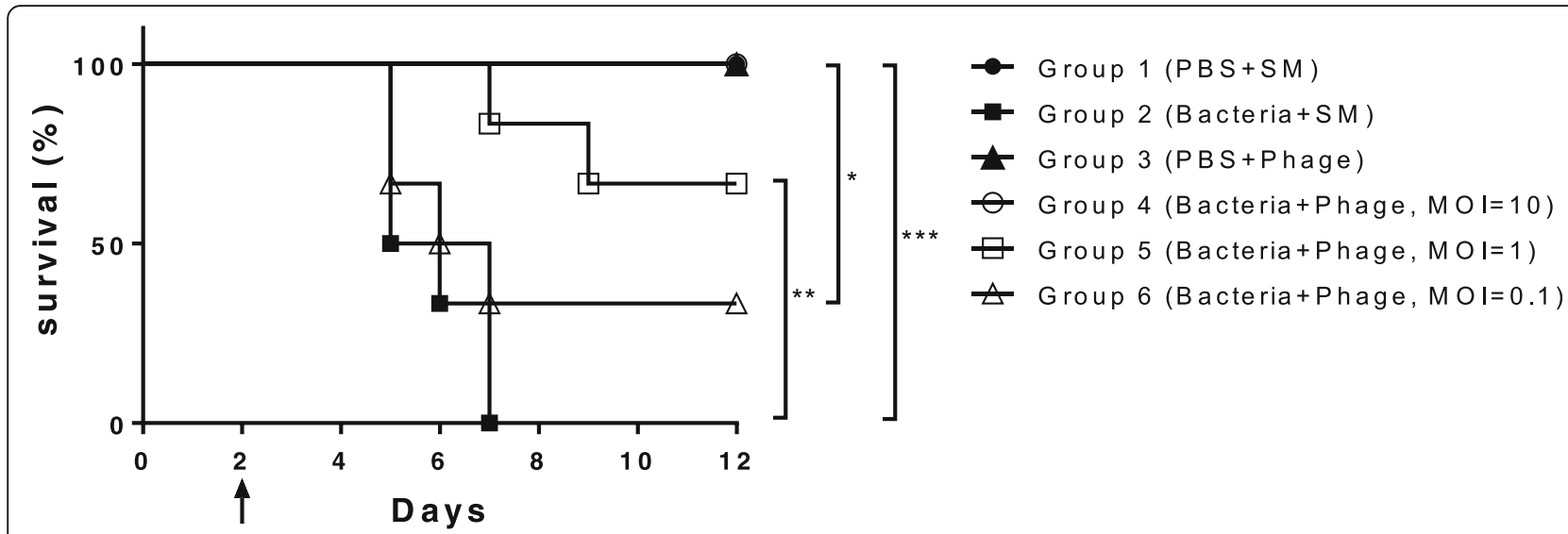

Fig. 5 Therapeutic effects of A. baumannii phage BQ-R2096 in a mouse model of acute pneumonia caused by carbapenem-resistant $A$. baumannii YMC13/03/R2096 strain. The C57BL/6 mice were intranasally inoculated with phage, bacteria, or both ( $n=6$ mice per group). Group 1 (control): PBS + SM buffer treatment; Group 2: A. baumannii-only-treatment; Group 3: phage B $\varphi$-R2096-only-treatment; Groups 4-6: postinfection phage B $\varphi$ R2096-treatment (MOI 10, 1, 0.1) 30 min after A. baumannii infection. A second cyclophosphamide (CP) and first bacteria treatment was given on day 2 (black arrow). Log-rank (Mantel-Cox) test, ${ }^{* * *} p<0.001,{ }^{*} p=0.0236$

$\mathrm{B} \phi-\mathrm{R} 2096$ is a CRAB-specific lytic phage that could be a promising antimicrobial agent to control CRAB.

To date, approximately $27 \mathrm{~A}$. baumannii phage genomes have been completely sequenced and deposited in the NCBI database (http://www.ncbi.nlm.nih.gov/genome/, May 1, 2018), and recently, the potential of therapeutic phage as a biocontrol agent against MDR- $A$. baumannii has been reported [44, 66-71]. Zhou W et al. [66] and Mathias Jansen et al. [67] presented synergy of antibiotics and phages for the control of A. baumannii strains in in vitro or in vivo, and Regeimbal JM et al. [44] and Yin S et al. [68] also stated the therapeutic efficacy of phage against $A$. baumannii using mouse wound infection model. LaVergne $S$ et al. [69] attempted human trial on a patient with the MDR-A. baumannii craniectomy site infection. However, there is little information studying the efficacy of phage therapy in the G. mellonella bacteremia and the mouse lung infection with CRAB clinical isolates. Jeon J et al. [71] and Yunfen Hua et al. [70] reported that in the intranasal treatment of monophage, phage therapy rescues the mice from lung infection caused by CRAB strains. In this study, we also investigated in details a novel Acinetobacter phage $\mathrm{B} \phi-\mathrm{R} 2096$ against $\mathrm{CRAB}$ clinical isolates in vivo and in vivo. In particular, to evaluate the therapeutic efficacy of phage, we employed the G. mellonella wax moth larvae infection and the mouse acute pneumonia model.

In a G. mellonella infection model, a single dose of phage B $\phi-R 2096$ increased survival rate of $G$. mellonella against CRAB clinical isolates. Moreover, the G. mellonella used in this study exhibited no toxicity from the concentrated phage $\left(1 \times 10^{10} \mathrm{PFU}\right)$ injections.

In a previous study, at low MOI, survival of G. mellonella was similar to that of our phage for $20 \mathrm{~h}$, but these
G. mellonella larvae were treated with phage cocktail [72]. In another study, although G. mellonella were treated with MOI of 0.1 showed higher survival of larvae than this study [66]; however, we used CRAB strain which includes the $16 \mathrm{~S}$ rRNA methylase gene armA clinical strain as host in this study.

Previous in vivo studies of the therapeutic potential of phages against bacterial pathogens such as $P$. aeruginosa, Clostridium difficile, Klebsiella pneumonia, and A. baumannii have used a G. mellonella infection model [44, $48,50,73,74]$. Also, some studies have shown a significant correlation between the G. mellonella model and a mouse infection model, moreover, phages improved survival in a dose dependent and time-dependent manner in these infection models; in fact, bacterial isolates are more virulent in the G. mellonella larval model than they are in the mouse model [74, 75]. Thus, compared with the mouse infection model, the G. mellonella larval model is a simpler, faster, more cost-effective, and more predictive model system for studying both the toxicity of pathogens and the therapeutic effects of phages against bacterial infections [74].

In the mouse acute pneumonia model, a single dose of phage B $\phi-\mathrm{R} 2096$ produced a strong therapeutic effect in all the mice. Especially, this phage exhibited approximately 2 to 3-fold higher survival rate at low MOI (MOI of 0.1) than that of Jeon J et al. [71] and Yunfen Hua et al. [70]. To investigate whether high-dose intranasal phage administration had side effects in this mouse model, we intranasally administered a high dose of phage B $\phi-\mathrm{R} 2096\left(10^{11} \mathrm{PFU} / \mathrm{ml}\right)$ to female C57BL/6 mice $(n=6)$. No deaths, decreases in bodyweight, or abnormal symptoms, such as lethargy, piloerection, or hunching occurred during the following 15 days (data not shown). 


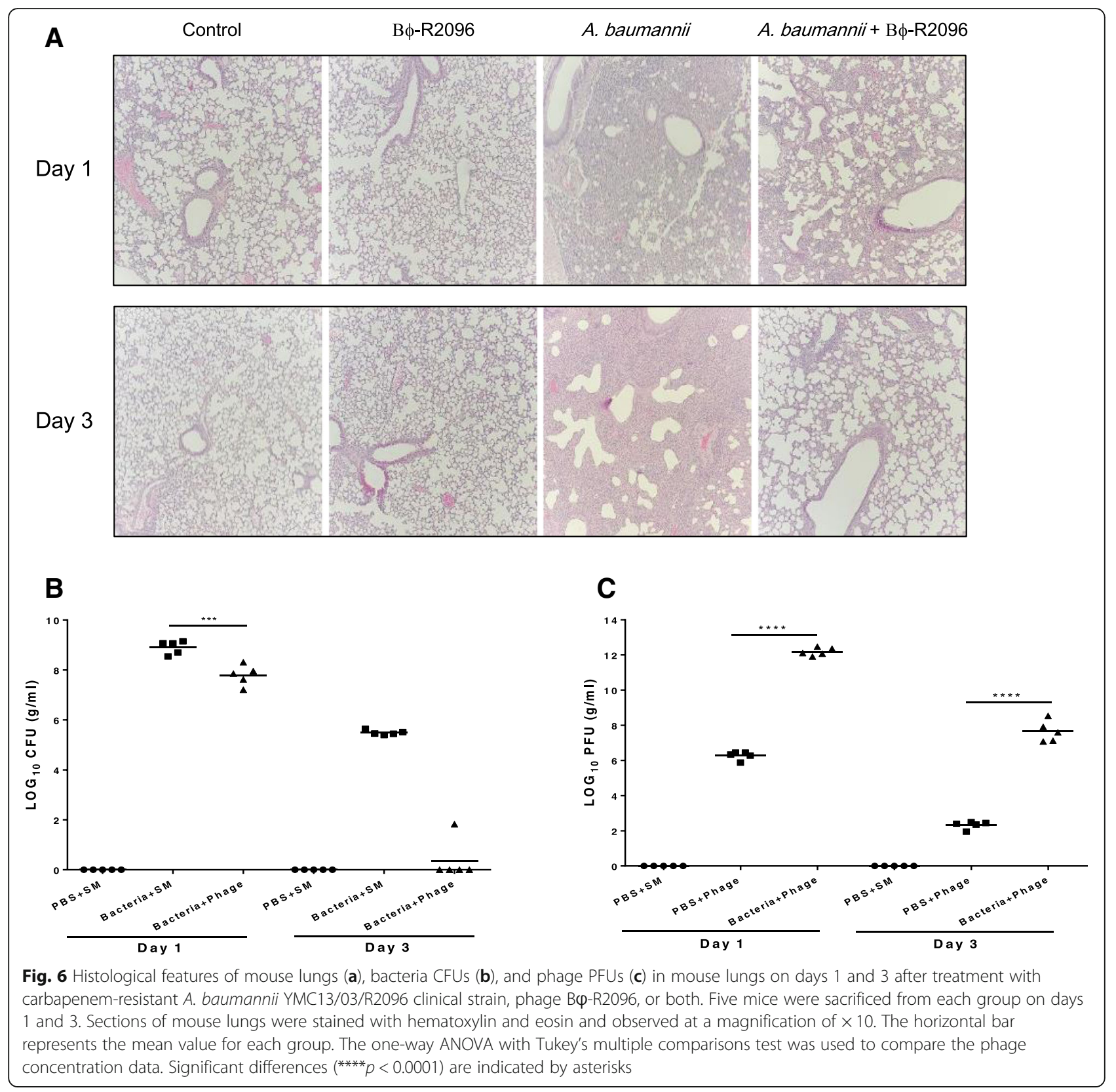

Also, none of those animals $(n=6)$ exhibited apparent histological changes in their lungs (data not shown). Therefore, the intranasal administration of a single high dose of phage B $\phi-R 2096$ had no significant side effects on the health of the animals in the mouse infection model. Our results thus show that phage B $\phi-R 2096$ can eliminate MDR pathogens and ameliorate disease symptoms in animals without causing any adverse effects.

In view of the correlation between the two in vivo models: although the two models used different infection routes for the phage and bacteria, and the larval model did not show survival rates as high as those in the mouse infection model, both models showed improvements from the phage treatment. Therefore, we suggest that in future studies, the G. mellonella model is an adequate animal model for assessing the safety and effectiveness of phage therapy.

\section{Conclusions}

Acinetobacter phage B $\phi-\mathrm{R} 2096$ is a newly discovered Myoviral bacteriophage, and we investigated its physiological characteristics and performed a whole genome analysis. Also, we evaluated its therapeutic effects against the carbapenem-resistant $A$. baumanniiYMC13/ 03/R2096 clinical strain in two animal infection models. 
Overall, phage $\mathrm{B} \phi-\mathrm{R} 2096$ showed a strong bacteriolytic activity in vitro and a significant reduction in mortality in both the G. mellonella larval model and the mouse acute pneumonia model; moreover, it ameliorated the pathogenic effects of the CRAB infection in both wax-moth larvae and mouse lungs. Interestingly, the two animal models also showed significant correlation for the efficacy of the phage as a therapeutic agent. In this study, our research strongly suggests that phage treatment can effectively eliminate pathogens and reduce the mortality of CRAB infections in vitro and in vivo. Therefore, we expect that phages will become new therapeutic agents for treating human pulmonary infections caused by clinical CRAB. Furthermore, the clear understanding of the physiological and molecular features of phages that we provided in this study proposes new promising strategies to control MDR pathogens. To the best of our knowledge, this is the first study to compare the therapeutic efficacy of a phage lysing CRAB between the $G$. mellonella infection model and the mouse acute pneumonia model.

\section{Methods}

\section{Bacterial strains}

The 20 CRAB strains used in this study to screen $A$. baumannii lytic phages were collected from patient samples taken at a tertiary-care hospital in Korea in 2013. The identification and antimicrobial susceptibility by CLSI guidelines of the CRAB clinical isolates were confirmed using previously published methods [76]. We selected 20 carbapenem-resistant and 11 carbapenem-sensitive $A$. baumannii clinical isolates for the host spectrum test of the isolated phage. We used pulsed-field gel electrophoresis (PFGE) to analyze bacterial genetic differences (Additional file 1: Figure S1). To describe the genetic backgrounds of the CRAB isolates, we conducted multilocus sequence typing (MLST), and we used a multiplex PCR assay to detect OXA carbapenemase genes in the CRAB strains [77]. The list of bacterial strains used in this study is given in Table 1. The carbapenem-resistant $A$. baumannii YMC13/03/R2096 strain from the sputum of a patient with pneumonia, the host bacteria of phage $\mathrm{B} \phi-\mathrm{R} 2096$, was used to study the preparation, physiological characteristics, and in vivo therapeutic effects of phage $\mathrm{B} \phi-\mathrm{R} 2096$. Eleven carbapenem-susceptible $A$. baumannii, three colistin-resistant $A$. baumannii, three carbapenem-resistant Pseudomonas aeruginosa, and three carbapenem-resistant Escherichia coli were used to determine the infectivity of phage $\mathrm{B} \phi-\mathrm{R} 2096$.

\section{Isolation of bacteriophage}

The CRAB lytic phages isolated from sewage samples of a hospital in South Korea were purified and concentrated using methods described previously [76, 78]. Briefly, the sewage water was treated $\mathrm{NaCl}(1 \mathrm{M})$ and polyethylene glycol (PEG) 8000 (total volume of $10 \%$, Sigma), incubated at $4{ }^{\circ} \mathrm{C}$ for $24 \mathrm{~h}$, filtered using $0.22 \mu \mathrm{m}$ membranes (Millipore Corporation, Bedford, MA, USA), and then centrifuged at $12,000 \times \mathrm{g}$ for $1 \mathrm{~h}$ at $4{ }^{\circ} \mathrm{C}$ and resuspended in sterilized sodium chloride-magnesium sulfate (SM) buffer (100 mM NaCl, $8 \mathrm{mM} \mathrm{MgSO}$, $2 \%$ gelatin, 50 $\mathrm{mM}$ Tris- $\mathrm{HCl}, \mathrm{pH} 7.5)$. The resuspended solution was mixed with $20 \mathrm{~A}$. baumannii strains and incubated at $37^{\circ} \mathrm{C}$ for $24 \mathrm{~h}$, and then the cultured solution was centrifuged and filtered. For initial phage isolation, spot tests were performed, and one single-clear plaque of the formed plaques by double-layer agar method was transferred in to a tube of LB broth using a sterile pipette tip. For phage purification, this process was repeated until one-plaque morphology was exhibited at least three times [61]. To concentrate the purified phages, we precipitated them using PEG 8000 (total volume of $10 \%)$, centrifuged them $\left(12,000 \times \mathrm{g}\right.$ at $4{ }^{\circ} \mathrm{C}$ for 1 h), and then resuspended them in SM buffer. Phage titration was calculated by the plaque assay using a double-layer method [78].

\section{Transmission electron microscopy}

Concentrated phage B $\phi-\mathrm{R} 2096$ (approximately $10^{11} \mathrm{PFU} /$ $\mathrm{ml}$ ) was adsorbed onto carbon-coated copper grids and negatively stained with $2 \%$ uranyl acetate for $15 \mathrm{~s}$. Phage morphologies were confirmed using a transmission electron microscope (JEOL JEM-101, Tokyo, Japan) at $80 \mathrm{kV}$.

\section{Host range test}

The host range of the purified phage against the collected clinical isolates was determined by spot tests, as described previously with some modifications [79]. Briefly, purified phage stock $\left(1 \times 10^{10} \mathrm{PFU} / \mathrm{ml}\right)$ was serially diluted with SM buffer. $5 \mu \mathrm{l}$ drop of diluted phage solution was spotted and dried on Luria-Bertani (LB) agar plates, each of which contained a different bacterial strain, and then the plates were incubated at $37^{\circ} \mathrm{C}$ for $12 \mathrm{~h}$. When clearing zones formed against each bacterial host, plaque clarity was evaluated as clear $(++)$, turbid $(+)$, and no plaque (-). Efficiency of plating (EOP) was evaluated using diluted phage suspension $\left(1 \times 10^{5} \mathrm{PFU} /\right.$ $\mathrm{ml}$ ) by the double-layer agar plate method, and was presented by the ratio of phage titer on the test strain to that on the host strain [80].

\section{Host cell lytic activity test}

The host bacterium, A. baumannii YMC13/03/R2096, was cultured up to $\mathrm{OD}_{600}=0.2$ at $37^{\circ} \mathrm{C}$ in $30 \mathrm{ml} \mathrm{LB}$ medium and mixed with the phage at a multiplicity of infection (MOI) of 0.1, 1, and 10. During shake-culturing at $37^{\circ} \mathrm{C}$, samples of $1 \mathrm{ml}$ were taken at $1 \mathrm{~h}$ intervals for $6 \mathrm{~h}$, and bacterial turbidity was measured by spectrophotometry at $\mathrm{OD}_{600} \mathrm{~nm}$; these tests were assessed in triplicate. 


\section{Genome sequencing and bioinformatics analysis}

Bacteriophage genomic DNA was extracted using standard phenol-chloroform extraction protocols, as described previously [81]. The genome sequencing of purified phage DNA was conducted at ChunLab, Inc. (Seoul, South Korea) using a 454 GS Junior Genome analyzer (Roche Life Sciences, Branford, CT, USA). The complete genome sequence was analyzed using the Roche gs Assembler (version 2.6; Roche) and CLC genomics wb 4.8 (CLCbio, Aarhus, Denmark). We compared it with the genome sequences of other phages using the NCBI database (http:// www.ncbi.nlm.nih.gov/). The prediction of open reading frames (ORFs) was performed using the NCBI ORF finder and GenMark.hmm software [82]. The putative promoter and rho-independent transcription terminators were predicted by using the Softberry program (http://www.softberry.com) and ARNOLD software (http://rna.igmors.upsud.fr/toolbox/arnold/), respectively. The tRNA genes were predicted by using the tRNAscan-SE program [83]. The similarities (blast $E$ value cutoff of 0.1 ) of all putative proteins were confirmed by BlastP and PSI-BLAST (http://www.ebi.ac.uk/Tools/sss/fasta/). A map of the annotated phage genome was generated using DNAPlotter [84], and phage genome was compared by using Easyfig software (version 2.1) [85].

\section{Galleria mellonella larvae infection model}

Galleria mellonella wax moth worms were used as an in vivo model to assess the therapeutic effects of the isolated $A$. baumannii lytic phage against $A$. baumannii clinical strains and were evaluated as described previously, with some modifications [86].

All the G. mellonella larvae were maintained on an artificial diet (25\% liquid honey, $20 \%$ glycerin, $5 \%$ dried beer yeast, $15 \%$ wheat flour, $15 \%$ skim milk powder and $20 \%$ polent) for 2 days at $25^{\circ} \mathrm{C}$. And larvae kept without food in a $90-\mathrm{mm}$ Petri dish in darkness for $24 \mathrm{~h}$ at $37^{\circ} \mathrm{C}$ before the experiments. Wax moth worms were randomly selected (weight $200-250 \mathrm{mg}$ ) and swabbed with $70 \%$ ethanol to reduce potential contamination caused by the injection. Larvae were divided into 5 groups: 1. Buffer (phosphate-buffered saline $[\mathrm{PBS}]+\mathrm{SM})$-only group, 2 . Bacteria-only-treatment $\left(1 \times 10^{8}\right.$ $\mathrm{CFU} / \mathrm{ml})$ group, 3. Phage-only-treatment group $\left(1 \times 10^{10}\right.$ $\mathrm{PFU} / \mathrm{ml}$ ), 4. Postinfection phage (MOI 100)-treatment group $\left(1 \times 10^{10} \mathrm{PFU} / \mathrm{ml}\right)$, and 5. Postinfection phage (MOI 10)-treatment group $\left(1 \times 10^{9} \mathrm{PFU} / \mathrm{ml}\right)$. Thirty minutes after larvae received $5 \mu \mathrm{l}$ of bacteria in the right side last proleg by injection, $5 \mu \mathrm{l}$ of phages or buffer were injected into a different last proleg using a 10- $\mu \mathrm{l}$ Hamilton syringe (701RN; Hamilton Bonaduz AG, Bonaduz, Switzerland). The injected larvae were incubated in the dark at $37^{\circ} \mathrm{C}$ in $90-\mathrm{mm}$ plastic Petri dishes and monitored for their survival at 8-h intervals for $48 \mathrm{~h}$. Galleria mellonella larvae were considered dead when they did not move in response to touch with a pipette tip. All experiments used 10 larvae per group and were repeated three times.

\section{Histology of larvae}

The collected larvae were processed for histology, as previously described with modifications [87]. Briefly, the larvae in each group were fixed in $10 \%$ formalin for 4 days (injected with $100 \mu \mathrm{l}$ of $10 \%$ formalin) and embedded in paraffin. The larval tissue sections were routinely stained with hematoxylin and eosin (H\&E), and the tissue morphology was observed using an optical microscope.

\section{Phage therapy in the mouse infection model}

To evaluate the therapeutic safety and efficacy of the bacteriophage in vivo, we used six groups of C57BL/6 mice (female aged 7-8 weeks) with six mice per group, divided as follows: group 1, buffer-only-treatment (PBS, Invitrogen, + $\mathrm{SM}$ ) mouse group; group 2, bacteria-only-treatment mouse group; group 3, phage-only-treatment mouse group; group 4-6, postinfection phage-treatment $(\mathrm{MOI}=10,1,0.1)$ mouse groups. Briefly, all of the mice used in the experiments were immunized by the intraperitoneal (i.p.) route using cyclophosphamide (200 mg/kg, Sigma-Aldrich) at 48-h intervals [88]. Mice were treated by the intranasal route with phage solution $\left(1 \times 10^{10} \mathrm{PFU} / \mathrm{ml}, 30 \mu \mathrm{l}\right)$ or $\mathrm{SM}$ buffer $30 \mathrm{~min}$ after infection with $1 \times 10^{9} \mathrm{CFU} / \mathrm{ml}, 30 \mu \mathrm{l}$, or PBS buffer administration by i.p. injection while anesthetized with Zoletil-Rompun. Each group was monitored for mortality, abnormal behavior, and body weight for 12 days.

For bacterial clearance, phage count, cytokine, and histology analyses, four groups of mice (ten mice per group) were divided as follows: group 1, buffer-only-treatment (PBS and $\mathrm{SM}$ ) mouse group; group 2, phage-only-treatment mouse group; group 3, bacteria-only-infection mouse group, and group 4 , postinfection phage-treatment $(\mathrm{MOI}=10)$ mouse group (30 min after infection). These mice did not receive cyclophosphamide injections. Mice were sacrificed on day 1 (five mice per group) or 3 (five mice per group) after measuring their body weights, and their lungs were collected. Blood was sampled from the eyes of the mice at the same time. The supernatants of the lung lysates and serum were stored at $-70^{\circ} \mathrm{C}$ for the cytokine analysis. The mice were euthanized through $\mathrm{CO}_{2}$ asphyxiation followed by cervical dislocation.

\section{Bacteria clearance and phage counting}

To determine bacterial counts in the mouse lungs at days 1 and 3 after bacterial infection, the lung samples from each group were homogenized and serially diluted in PBS and then plated onto LB agar plates with ampicillin $(50 \mu \mathrm{g} / \mathrm{ml})$. To assess the bacteriophages, the supernatants of the lung and blood samples collected from each mouse group were 
serially diluted and counted using the double-layer agar method at each time point.

\section{Histology of mouse lungs}

Mouse lungs were processed for histology, as previously described with modifications [89]. Briefly, to evaluate histological features, the right lung tissues were removed and fixed in $10 \%$ formalin. The specimen were dehydrated in graded alcohol and embedded in paraffin. The lung tissue sections of $3 \mu \mathrm{m}$-thick were stained with $H \& E$ and observed using an optical microscope.

\section{Ethics statement}

All animal experiments followed the regulations of the Institutional Animal Care and Use Committee of Yonsei University College of Medicine, Seoul, Korea (IACUC Approval no. 2014-0031-2).

\section{Statistical analysis}

We used the log-rank (Mantel-Cox) test and statistical software (GraphPad Prism Software, version 6; GraphPad Software, San Diego, CA, USA) to compare groups in the survival curve test. A one-way ANOVA followed by Tukey's test (GraphPad Prism Software) was used to compare statistical calculations for bacterial and phage titers.

\section{Additional file}

Additional file 1: Figure S1. Pulsed-field gel electrophoresis (PFGE) anaIysis of 31 carbapenem-resistant and -susceptible A. baumannii isolates. Figure S2. The adsorption rate (A) and one-step growth curve (B) of $A$. baumannii phage $B \varphi-R 2096$ on A. baumannii strain YMC13/03/R2096. Figure S3. Temperature and $\mathrm{pH}$ stability of $A$. baumannii phage $B \varphi$ R2096 on A. baumannii strain YMC13/03/R2096. Figure S4. Body weight of C57BL/6 mice infected with A. baumannii phage $B \varphi-R 2096$, A. baumannii YMC13/03/R2096, or both. Figure S5. The concentration of cytokines (TNF-a, IL-6, and IL-1 $\beta$ ) in the lungs of mice on days 1 and 3 after treatment with A. baumannii YMC13/03/R2096, phage BQ-R2096, or both. Table S1. Antibiotic resistance profiles of carbapenem-resistant $A$. baumannii clinical strains used in this study. Table S2. A. baumannii phage B $\varphi-R 2096$ ORFs summary. (DOCX $698 \mathrm{~kb}$ )

\section{Abbreviations}

CFU: Colony forming units; CRAB: carbapenem-resistant Acinetobacter baumannii; EOP: Efficiency of plating; ESKAPE: Enterococcus faecium, Staphylococcus aureus, Klebsiella pneumoniae, Acinetobacter baumannii, Pseudomonas aeruginosa, and Enterobacter species; MLST: multilocus sequence typing; MOI: Multiplicity of infection; PFGE: pulsed-field gel electrophoresis; PFU: Plaque forming units

\section{Acknowledgments}

We are grateful to Ms. Sori Jong (Research Institute of Bacterial Resistance, Yonsei University College of Medicine, Seoul, Republic of Korea) for technical assistance.

\section{Funding}

This work was supported by the Basic Science Research Program through the National Research Foundation of Korea (NRF) funded by the Ministry of Education (NRF-2017R1D1A1B03034730); by the BioNano Health-Guard Research Center funded by the Ministry of Science, ICT \& Future Planning (MSIP) of Korea as a Global Frontier Project (Grant Number H-
GUARD_2014M3A6B2060509); by a faculty research grant of Yonsei University College of Medicine (6-2014-0039); and by the Nano Material Technology Development Program through the National Research Foundation of Korea (NRF) funded by the Ministry of Science and ICT (No.2017M3A7B4039936). Funding bodies had no roles in the design of the study and collection, analysis, and interpretation of data and in writing the manuscript.

\section{Availability of data and materials}

The complete genome sequences of A. baumannii bacteriophage $B \phi-R 2096$ is accessible in the GenBank database under accession number KM672662.

\section{Authors' contributions}

JJ, PJ and YD designed the study. JJ performed the experiments and wrote the manuscript. JJ and YD contributed to manuscript discussion and revision. PJ and YD contributed to overall support of this study. All authors read and approved the final manuscript.

\section{Ethics approval and consent to participate}

All animal experiments followed the regulations of the Institutional Animal Care and Use Committee of Yonsei University College of Medicine, Seoul, Korea (IACUC Approval no. 2014-0031-2). The IRB committee of Yonsei University Health System ruled the study was exempt from the need for ethics approval for the use of bacterial strains taken from patients and also ruled that consent to participate was waived (IRB approval number 4-2019-0023).

\section{Consent for publication}

Not applicable.

\section{Competing interests}

The authors declare that they have no competing interests.

\section{Publisher's Note}

Springer Nature remains neutral with regard to jurisdictional claims in published maps and institutional affiliations.

\section{Author details}

${ }^{1}$ Department of Laboratory Medicine and Research Institute of Bacterial Resistance, Y, Seoul, Republic of Korea. ${ }^{2}$ Laboratory Animal Medicine, College of Veterinary Medicine, Chonnam National University, Gwang-ju 61186, Republic of Korea. ${ }^{3}$ Department of Laboratory Medicine and Research Institute of Bacterial Resistance, Yonsei University College of Medicine, 50-1Yonsei-ro, Seodaemun-gu, Seoul 03722, South Korea.

Received: 9 September 2018 Accepted: 25 March 2019

Published online: 02 April 2019

\section{References}

1. Jean SS, Hsueh PR. High burden of antimicrobial resistance in Asia. Int J Antimicrob Agents. 2011;37(4):291-5.

2. Van Looveren $\mathrm{M}$, Goossens $\mathrm{H}$. Antimicrobial resistance of Acinetobacter spp. in Europe. Clin Microbiol Infect. 2004;10(8):684-704.

3. Acar J, Rostel B. Antimicrobial resistance: an overview. Rev Sci Tech. 2001; 20(3):797-810

4. Levy SB, Marshall B. Antibacterial resistance worldwide: causes, challenges and responses. Nat Med. 2004:10(12 Suppl):S122-9.

5. Bergogne-Berezin E, Towner KJ. Acinetobacter spp. as nosocomial pathogens: microbiological, clinical, and epidemiological features. Clin Microbiol Rev. 1996;9(2):148-65

6. Pendleton JN, Gorman SP, Gilmore BF. Clinical relevance of the ESKAPE pathogens. Expert Rev Anti-Infect Ther. 2013;11(3):297-308.

7. Kempf M, Rolain JM. Emergence of resistance to carbapenems in Acinetobacter baumannii in Europe: clinical impact and therapeutic options. Int J Antimicrob Agents. 2012;39(2):105-14.

8. Munoz-Price LS, Weinstein RA. Acinetobacter infection. N Engl J Med. 2008; 358(12):1271-81.

9. Fu Y, Zhou J, Zhou H, Yang Q, Wei Z, Yu Y, Li L. Wide dissemination of OXA-23-producing carbapenem-resistant Acinetobacter baumannii clonal complex 22 in multiple cities of China. J Antimicrob Chemother. 2010;65(4): 644-50

10. Lee K, Kim MN, Kim JS, Hong HL, Kang JO, Shin JH, Park YJ, Yong D, Jeong $\mathrm{SH}$, Chong $\mathrm{Y}$, et al. Further increases in carbapenem-, amikacin-, and 
fluoroquinolone-resistant isolates of Acinetobacter spp. and P. Aeruginosa in Korea: KONSAR study 2009. Yonsei Med J. 2011;52(5):793-802.

11. Lee K, Kim MN, Choi TY, Cho SE, Lee S, Whang DH, Yong D, Chong Y, Woodford N, Livermore DM, et al. Wide dissemination of OXA-type carbapenemases in clinical Acinetobacter spp. isolates from South Korea. Int J Antimicrob Agents. 2009;33(6):520-4.

12. Manikal VM, Landman D, Saurina G, Oydna E, Lal H, Quale J. Endemic carbapenem-resistant Acinetobacter species in Brooklyn, New York: citywide prevalence, interinstitutional spread, and relation to antibiotic usage. Clin Infect Dis. 2000;31(1):101-6.

13. Dijkshoorn L, Nemec A, Seifert H. An increasing threat in hospitals: multidrugresistant Acinetobacter baumannii. Nat Rev Microbiol. 2007;5(12):939-51.

14. Higgins PG, Dammhayn C, Hackel M, Seifert H. Global spread of carbapenemresistant Acinetobacter baumannii. J Antimicrob Chemother. 2010;65(2):233-8.

15. Kwon KT, Oh WS, Song JH, Chang HH, Jung SI, Kim SW, Ryu SY, Heo ST, Jung DS, Rhee JY, et al. Impact of imipenem resistance on mortality in patients with Acinetobacter bacteraemia. J Antimicrob Chemother. 2007;59(3):525-30.

16. Sunenshine RH, Wright MO, Maragakis LL, Harris AD, Song X, Hebden J, Cosgrove SE, Anderson A, Carnell J, Jernigan DB, et al. Multidrug-resistant Acinetobacter infection mortality rate and length of hospitalization. Emerg Infect Dis. 2007:13(1):97-103.

17. Hu WS, Yao SM, Fung CP, Hsieh YP, Liu CP, Lin JF. An OXA-66/OXA-51-like carbapenemase and possibly an efflux pump are associated with resistance to imipenem in Acinetobacter baumannii. Antimicrob Agents Chemother. 2007:51(11):3844-52

18. Fernandez-Cuenca F, Martinez-Martinez L, Conejo MC, Ayala JA, Perea EJ, Pascual A. Relationship between beta-lactamase production, outer membrane protein and penicillin-binding protein profiles on the activity of carbapenems against clinical isolates of Acinetobacter baumannii. J Antimicrob Chemother. 2003;51(3):565-74.

19. Walther-Rasmussen J, Hoiby N. OXA-type carbapenemases. J Antimicrob Chemother. 2006;57(3):373-83.

20. Yong D, Choi YS, Roh KH, Kim CK, Park YH, Yum JH, Lee K, Chong Y. Increasing prevalence and diversity of metallo-beta-lactamases in Pseudomonas spp., Acinetobacter spp., and Enterobacteriaceae from Korea. Antimicrob Agents Chemother. 2006;50(5):1884-6.

21. Carvalho KR, Carvalho-Assef AP, Peirano G, Santos LC, Pereira MJ, Asensi MD. Dissemination of multidrug-resistant Acinetobacter baumannii genotypes carrying Bla(OXA-23) collected from hospitals in Rio de Janeiro, Brazil. Int J Antimicrob Agents. 2009;34(1):25-8.

22. Lee CS, Doi Y. Therapy of infections due to Carbapenem-resistant gramnegative pathogens. Infect Chemother. 2014;46(3):149-64.

23. Cai Y, Chai D, Wang R, Liang B, Bai N. Colistin resistance of Acinetobacter baumannii: clinical reports, mechanisms and antimicrobial strategies. J Antimicrob Chemother. 2012;67(7):1607-15.

24. Ko KS, Suh JY, Kwon KT, Jung SI, Park KH, Kang Cl, Chung DR, Peck KR, Song $\mathrm{JH}$. High rates of resistance to colistin and polymyxin B in subgroups of Acinetobacter baumannii isolates from Korea. J Antimicrob Chemother. 2007; 60(5):1163-7.

25. Lolans K, Rice TW, Munoz-Price LS, Quinn JP. Multicity outbreak of carbapenem-resistant Acinetobacter baumannii isolates producing the carbapenemase OXA-40. Antimicrob Agents Chemother. 2006;50(9):2941-5.

26. Falagas ME, Kasiakou SK. Toxicity of polymyxins: a systematic review of the evidence from old and recent studies. Crit Care. 2006;10(1):R27.

27. Abedon ST, Kuhl SJ, Blasdel BG, Kutter EM. Phage treatment of human infections. Bacteriophage. 2011;1(2):66-85.

28. Alisky J, Iczkowski K, Rapoport A, Troitsky N. Bacteriophages show promise as antimicrobial agents. J Inf Secur. 1998;36(1):5-15.

29. Kutateladze M, Adamia R. Bacteriophages as potential new therapeutics to replace or supplement antibiotics. Trends Biotechnol. 2010;28(12):591-5.

30. Lu TK, Koeris MS. The next generation of bacteriophage therapy. Curr Opin Microbiol. 2011;14(5):524-31.

31. Sulakvelidze A, Alavidze Z, Morris JG, Jr. Bacteriophage therapy. Antimicrob Agents Chemother 2001:45(3):649-659.

32. Merril CR, Scholl D, Adhya SL. The prospect for bacteriophage therapy in Western medicine. Nat Rev Drug Discov. 2003;2(6):489-97.

33. Brussow $\mathrm{H}$. What is needed for phage therapy to become a reality in Western medicine? Virology. 2012;434(2):138-42.

34. Burrowes B, Harper DR, Anderson J, McConville M, Enright MC. Bacteriophage therapy: potential uses in the control of antibiotic-resistant pathogens. Expert Rev Anti-Infect Ther. 2011;9(9):775-85.
35. Chan BK, Abedon ST, Loc-Carrillo C. Phage cocktails and the future of phage therapy. Future Microbiol. 2013;8(6):769-83.

36. Haq IU, Chaudhry WN, Akhtar MN, Andleeb S, Qadri I. Bacteriophages and their implications on future biotechnology: a review. Virol J. 2012;9:9.

37. Soothill JS. Treatment of experimental infections of mice with bacteriophages. J Med Microbiol. 1992;37(4):258-61.

38. Huang G, Le S, Peng Y, Zhao Y, Yin S, Zhang L, Yao X, Tan Y, Li M, Hu F. Characterization and genome sequencing of phage Abp1, a new phiKMVlike virus infecting multidrug-resistant Acinetobacter baumannii. Curr Microbiol. 2013;66(6):535-43.

39. Jin J, Li Z Z, Wang SW, Wang SM, Huang DH, Li YH, Ma YY, Wang J, Liu F, Chen XD, et al. Isolation and characterization of ZZ1, a novel lytic phage that infects Acinetobacter baumannii clinical isolates. BMC Microbiol. 2012;12:156.

40. Peng F, Mi Z, Huang Y, Yuan X, Niu W, Wang Y, Hua Y, Fan H, Bai C, Tong Y. Characterization, sequencing and comparative genomic analysis of $\mathrm{VB}_{-}$ AbaM-IME-AB2, a novel lytic bacteriophage that infects multidrug-resistant Acinetobacter baumannii clinical isolates. BMC Microbiol. 2014;14:181.

41. Yele AB, Thawal ND, Sahu PK, Chopade BA. Novel lytic bacteriophage AB7IBB1 of Acinetobacter baumannii: isolation, characterization and its effect on biofilm. Arch Virol. 2012;157(8):1441-50.

42. Schooley RT, Biswas B, Gill JJ, Hernandez-Morales A, Lancaster J, Lessor L, Barr JJ, Reed SL, Rohwer F, Benler S, et al. Development and use of personalized bacteriophage-based therapeutic cocktails to treat a patient with a disseminated resistant Acinetobacter baumannii infection. Antimicrob Agents Chemother. 2017;61(10).

43. Kusradze I, Karumidze N, Rigvava S, Dvalidze T, Katsitadze M, Amiranashvili I, Goderdzishvili M. Characterization and testing the efficiency of Acinetobacter baumannii phage vB-GEC_Ab-M-G7 as an antibacterial agent. Front Microbiol. 2016;7:1590

44. Regeimbal JM, Jacobs AC, Corey BW, Henry MS, Thompson MG, Pavlicek RL, Quinones J, Hannah RM, Ghebremedhin M, Crane NJ, et al. Personalized therapeutic cocktail of wild environmental phages rescues mice from Acinetobacter baumannii wound infections. Antimicrob Agents Chemother. 2016;60(10):5806-16.

45. Labrie SJ, Samson JE, Moineau S. Bacteriophage resistance mechanisms. Nat Rev Microbiol. 2010;8(5):317-27.

46. Chan BK, Abedon ST. Phage therapy pharmacology. phage cocktails Adv Appl Microbiol. 2012;78:1-23.

47. Cooper CJ, Khan Mirzaei M, Nilsson AS. Adapting drug approval pathways for bacteriophage-based therapeutics. Front Microbiol. 2016;7:1209.

48. Nale JY, Chutia M, Carr P, Hickenbotham PT, Clokie MR. 'Get in Early'; biofilm and wax moth (galleria mellonella) models reveal new insights into the therapeutic potential of Clostridium difficile bacteriophages. Front Microbiol. 2016;7:1383.

49. Mukherjee K, Altincicek B, Hain T, Domann E, Vilcinskas A, Chakraborty T. Galleria mellonella as a model system for studying Listeria pathogenesis. Appl Environ Microbiol. 2010;76(1):310-7.

50. Beeton ML, Alves DR, Enright MC, Jenkins AT. Assessing phage therapy against Pseudomonas aeruginosa using a Galleria mellonella infection model. Int J Antimicrob Agents. 2015;46(2):196-200.

51. Kamal F, Dennis JJ. Burkholderia cepacia complex phage-antibiotic synergy (PAS): antibiotics stimulate lytic phage activity. Appl Environ Microbiol. 2015; 81(3):1132-8.

52. Keen EC. Phage therapy: concept to cure. Front Microbiol. 2012;3:238.

53. Falagas ME, Koletsi PK, Bliziotis IA. The diversity of definitions of multidrugresistant (MDR) and pandrug-resistant (PDR) Acinetobacter baumannii and Pseudomonas aeruginosa. J Med Microbiol. 2006;55(Pt 12:1619-29.

54. Wittebole X, De Roock S, Opal SM. A historical overview of bacteriophage therapy as an alternative to antibiotics for the treatment of bacterial pathogens. Virulence. 2014;5(1):226-35.

55. Oduor JM, Onkoba N, Maloba F, Arodi WO, Nyachieo A. Efficacy of lytic Staphylococcus aureus bacteriophage against multidrug-resistant Staphylococcus aureus in mice. J Infect Dev Ctries. 2016;10(11):1208-13.

56. Gu J, Li X, Yang M, Du C, Cui Z, Gong P, Xia F, Song J, Zhang L, Li J, et al. Therapeutic effect of Pseudomonas aeruginosa phage YH30 on mink hemorrhagic pneumonia. Vet Microbiol. 2016;190:5-11.

57. Dufour N, Clermont O, La Combe B, Messika J, Dion S, Khanna V, Denamur E, Ricard JD, Debarbieux L. Bacteriophage LM33_P1, a fast-acting weapon against the pandemic ST131-O25b:H4 Escherichia coli clonal complex. J Antimicrob Chemother. 2016;71(11):3072-80.

58. Mahony J, McAuliffe O, Ross RP, van Sinderen D. Bacteriophages as biocontrol agents of food pathogens. Curr Opin Biotechnol. 2011;22(2): $157-63$. 
59. Sung JY, Koo SH, Cho HH, Kwon KC. Nosocomial infection by sequence type 357 multidrug-resistant Acinetobacter baumannii isolates in a neonatal intensive care unit in Daejeon, Korea. Ann Lab Med. 2013;33(4):279-82.

60. Lee $\mathrm{H}$, Yong D, Yum JH, Roh KH, Lee K, Yamane K, Arakawa Y, Chong Y. Dissemination of 165 rRNA methylase-mediated highly amikacin-resistant isolates of Klebsiella pneumoniae and Acinetobacter baumannii in Korea. Diagn Microbiol Infect Dis. 2006;56(3):305-12.

61. Popova AV, Zhilenkov EL, Myakinina VP, Krasilnikova VM, Volozhantsev NV. Isolation and characterization of wide host range lytic bacteriophage AP22 infecting Acinetobacter baumannii. FEMS Microbiol Lett. 2012;332(1):40-6.

62. Hernandez-Morales AC, Lessor LL, Wood TL, Migl D, Mijalis EM, Russell WK, Young RF, Gill JJ. Genomic and biochemical characterization of Acinetobacter Podophage Petty reveals a novel lysis mechanism and tailassociated Depolymerase activity. J Virol. 2018. https://doi.org/10.1128/jvi. 01064-17.

63. Cha K, Oh HK, Jang JY, Jo Y, Kim WK, Ha GU, Ko KS, Myung H. Characterization of two novel bacteriophages infecting multidrug-resistant (MDR) Acinetobacter baumannii and evaluation of their therapeutic efficacy in Vivo. Front Microbiol. 2018;9:696.

64. Yang $H$, Liang $L$, Lin S, Jia S. Isolation and characterization of a virulent bacteriophage AB1 of Acinetobacter baumannii. BMC Microbiol. 2010;10:131.

65. Abedon ST. Lysis from without. Bacteriophage. 2011;1(1):46-9.

66. Zhou W, Feng Y, Zong Z. Two new lytic bacteriophages of the Myoviridae family against Carbapenem-resistant Acinetobacter baumannii. Front Microbiol. 2018;9:850.

67. Jansen M, Wahida A, Latz S, Krüttgen A, Häfner H, Buhl EM, Ritter K, Horz H$P$. Enhanced antibacterial effect of the novel T4-like bacteriophage KARL-1 in combination with antibiotics against multi-drug resistant Acinetobacter baumannii. Sci Rep. 2018;8(1):14140.

68. Yin S, Huang G, Zhang Y, Jiang B, Yang Z, Dong Z, You B, Yuan Z, Hu F, Zhao $Y$, et al. Phage Abp1 rescues human cells and mice from infection by pan-drug resistant Acinetobacter baumannii. Cell Physiol Biochem. 2017; 44(6):2337-45.

69. LaVergne S, Hamilton T, Biswas B, Kumaraswamy M, Schooley RT, Wooten D. Phage therapy for a multidrug-resistant Acinetobacter baumannii Craniectomy site infection. Open Forum Infect Dis. 2018;5(4):ofy064.

70. Hua Y, Luo T, Yang Y, Dong D, Wang R, Wang Y, Xu M, Guo X, Hu F, He P. Phage therapy as a promising new treatment for lung infection caused by Carbapenem-resistant Acinetobacter baumannii in mice. Front Microbiol. 2017:8:2659.

71. Jeon J, Ryu CM, Lee JY, Park JH, Yong D, Lee K. In vivo application of bacteriophage as a potential therapeutic agent to control OXA-66-like Carbapenemase-producing Acinetobacter baumannii strains belonging to sequence type 357. Appl Environ Microbiol. 2016;82(14):4200-8.

72. Forti F, Roach DR, Cafora M, Pasini ME, Horner DS, Fiscarelli EV, Rossitto M, Cariani L, Briani F, Debarbieux L, et al. Design of a Broad-Range Bacteriophage Cocktail that Reduces Pseudomonas aeruginosa biofilms and treats acute infections in two animal models. Antimicrob Agents Chemother. 2018;62(6).

73. D'Andrea MM, Marmo P, Henrici De Angelis L, Palmieri M, Ciacci N, Di Lallo G, Dematte E, Vannuccini E, Lupetti P, Rossolini GM, et al. phiBO1E, a newly discovered lytic bacteriophage targeting carbapenemase-producing Klebsiella pneumoniae of the pandemic clonal group 258 clade II lineage. Sci Rep. 2017;7(1):2614.

74. Tsai CJ, Loh JM, Proft T. Galleria mellonella infection models for the study of bacterial diseases and for antimicrobial drug testing. Virulence. 2016. https://doi.org/10.1080/21505594.2015.1135289:1-16.

75. Brennan M, Thomas DY, Whiteway M, Kavanagh K. Correlation between virulence of Candida albicans mutants in mice and Galleria mellonella larvae. FEMS Immunol Med Microbiol. 2002;34(2):153-7.

76. Jeon J, D'Souza R, Pinto N, Ryu CM, Park J, Yong D, Lee K. Characterization and complete genome sequence analysis of two Myoviral bacteriophages infecting clinical carbapenem-resistant Acinetobacter baumannii isolates. J Appl Microbiol. 2016. https://doi.org/10.1111/jam.13134.

77. Woodford N, Ellington MJ, Coelho JM, Turton JF, Ward ME, Brown S, Amyes SG, Livermore DM. Multiplex PCR for genes encoding prevalent OXA carbapenemases in Acinetobacter spp. Int J Antimicrob Agents. 2006;27(4): 351-3.

78. Kropinski AM, Mazzocco A, Waddell TE, Lingohr E, Johnson RP. Enumeration of bacteriophages by double agar overlay plaque assay. Methods Mol Biol. 2009;501:69-76.
79. Lin NT, Chiou PY, Chang KC, Chen LK, Lai MJ. Isolation and characterization of phi AB2: a novel bacteriophage of Acinetobacter baumannii. Res Microbiol. 2010;161(4):308-14.

80. Frampton RA, Taylor C, Holguin Moreno AV, Visnovsky SB, Petty NK, Pitman $A R$, Fineran PC. Identification of bacteriophages for biocontrol of the kiwifruit canker phytopathogen Pseudomonas syringae pv. actinidiae. Appl Environ Microbiol. 2014;80(7):2216-28

81. Wilcox SA, Toder R, Foster JW. Rapid isolation of recombinant lambda phage DNA for use in fluorescence in situ hybridization. Chromosom Res. 1996;4(5):397-8.

82. Besemer J, Lomsadze A, Borodovsky M. GeneMarkS: a self-training method for prediction of gene starts in microbial genomes. Implications for finding sequence motifs in regulatory regions. Nucleic Acids Res. 2001;29(12):2607-18.

83. Lowe TM, Eddy SR. tRNAscan-SE: a program for improved detection of transfer RNA genes in genomic sequence. Nucleic Acids Res. 1997;25(5): 955-64.

84. Carver T, Thomson N, Bleasby A, Berriman M, Parkhill J. DNAPlotter: circular and linear interactive genome visualization. Bioinformatics. 2009;25(1):119-20.

85. Sullivan MJ, Petty NK, Beatson SA. Easyfig: a genome comparison visualizer. Bioinformatics. 2011;27(7):1009-10.

86. Abbasifar R, Kropinski AM, Sabour PM, Chambers JR, MacKinnon J, Malig T, Griffiths MW. Efficiency of bacteriophage therapy against Cronobacter sakazakii in Galleria mellonella (greater wax moth) larvae. Arch Virol. 2014; 159(9):2253-61.

87. Perdoni F, Falleni M, Tosi D, Cirasola D, Romagnoli S, Braidotti P, Clementi E, Bulfamante $\mathrm{G}$, Borghi E. A histological procedure to study fungal infection in the wax moth Galleria mellonella. Eur J Histochem. 2014;58(3):2428.

88. Manepalli S, Gandhi JA, Ekhar W, Asplund MB, Coelho C, Martinez LR. Characterization of a cyclophosphamide-induced murine model of immunosuppression to study Acinetobacter baumannii pathogenesis. J Med Microbiol. 2013;62(Pt 11:1747-54

89. Morello E, Saussereau E, Maura D, Huerre M, Touqui L, Debarbieux L. Pulmonary bacteriophage therapy on Pseudomonas aeruginosa cystic fibrosis strains: first steps towards treatment and prevention. PLOS One. 2011;6(2):e16963.

\section{Ready to submit your research? Choose BMC and benefit from:}

- fast, convenient online submission

- thorough peer review by experienced researchers in your field

- rapid publication on acceptance

- support for research data, including large and complex data types

- gold Open Access which fosters wider collaboration and increased citations

- maximum visibility for your research: over $100 \mathrm{M}$ website views per year

At BMC, research is always in progress.

Learn more biomedcentral.com/submissions 